\title{
Pohledy z druhého břehu: Transnacionalismus, rituál a sociální změna
}

\author{
Views from the Other Shore: Transnationalism, Ritual and Social \\ Change
}

David Henig

\begin{abstract}
In a globalised and mutually interconnected world, after the post-modern turn in social sciences, does anthropology offer any way to understand complexity of human life and society? Transnational studies offer a powerful set of explanatory tools for knowledge production and analysis. While this approach has produced a number of valuable contributions and insights, it is hampered by certain assumptions that may distort knowledge production. In this paper I argue that transnational anthropology may represent a moderate way of knowledge production on transnationalism, combining both interest on micropolitics of human life as well as their transnational interconnectedness.

Using ethnographic data on transnational networks from Pakistan, Morocco, Bangladesh and Daghestan, I re-construct the omitted view in the transnational studies: a view from the other shore where the attention is paid to actors who have been left behind, as a consequence of transnational migration, on the other shores. Through careful examination of particular life cycle rituals, I explore changes effected by recent shifts in capital (as conventionally understood) and symbolic capital (as outlined by Bourdieu) mediated by transnational networks. Therefore, I argue that any postmodern reflexivity and intellectual fashion should not replace ethnographic sensitivity from transnational studies.
\end{abstract}

KEY WORDS ethnography, ritual, social change, symbolic dominance, transnational anthropology

„Jak se mohu smířit s tím, že můj manžel odjel do Londýna?“ Ženy zpívají, „Zabalím mu do kufru sušenou rybu / Všichni mullahové - úplně každý - odjeli do Londýna / Země bude prázdná - co si počnu? / Když jede můj bratr do Londýna, udělá objednávky u krejčího / Nechá pro mě ušít halenku / Jak mohu přijmout, že můj manžel odjel do Londýna?““ (Gardner 1993: 1)

Tuto píseň je možné zaslechnout v oblasti bangladéšského Silhet v různých variantách po několik posledních desetiletí. Jedná se o píseň vystihující napětí mezi bidesh a desh, mezi cizinou a domovem. Bangladéšský Silhet je jedno z mnoha míst, která se stala součástí globálních krajin. Hranice mezi bidesh a desh je poslední desetiletí permanentně stírána transnacionálními vazbami, které obyvatelé Silhet udržují se svými blízkými, již zakotvili

Sociální studia. Fakulta sociálních studií Masarykovy univerzity, 1/2009. S. 169-186. ISSN 1214-813X. 
především v londýnském Tower Hamlet. Tato spojnice není v současnosti nikterak výjimečná. Globalizace, tedy intenzifikace pohybu lidí, slov a myšlenek, rýsuje spojnice mezi pákistánským Paňdžábem a Manchesterem, mezi Srí Lankou a Norskem, mezi Bosnou a Londýnem a tak dál (Al-Ali 2002, Fuglerud 1999, Werbner 2002). Prostřednictvím těchto vazeb proudí mezi geografickými místy rozptýlenými po glóbu komodity, dary, manželé i manželky, myšlenky a symboly. Toto proudění celkově vytvárí signifikantní sociální mikrosvěty, v nichž se daní jedinci angažují. Geografické hranice a vzdálenosti jsou v těchto mikrosvětech stírány prostřednictvím rozvoje technologií i zmasověním mezinárodní přepravy (Vertovec 2004). Klíčovou roli v životě transmigrantů však představuje rovina imaginace: schopnost představovat si své přináležení $\mathrm{k}$ partikulárním deteritorializovaným sociálním mikrosvětům (Appadurai 1996, Gupta a Ferguson 1997).

Studium těchto sociálních mikrosvětů a jejich aktérů se stalo předmětem studia transnacionální antropologie. Hlavní pozornost začala být zaměřována na studium transnacionálních migrantů; na jejich život mezi (in between); na jejich pohyb mezi cizinou a domovem; na rétoriku, imaginaci a jednání, jež jsou využívány k naplňování a osmyslování života tady a ted'. Ve své zhuštěné definici Werbner definuje transmigranta jako ,a migrant who moves back and forth between the West and the Rest" (Werbner 2004: 896). V této definici je vyjádřen posun $\mathrm{v}$ celkovém prístupu $\mathrm{k}$ tomu, jak konceptualizovat migraci na počátku jedenadvacátého století. Jedná se o posun od funkcionální (Bogue) $\mathrm{k}$ dynamické perspektivě (Appadurai); a v termínech politické ekonomie od světového systému (Wallerstein) ke světu sítí (Castells). Ulf Hannerz (1998) o transnacionálně-antropologickém výzkumu poznamenal, že by měl studovat sociální sítě transmigrantů a věnovat pozornost všem bodům v dané transnacionální síti. Neměl by být zacílen pouze na transmigranty, ale na celou sociální sít, jíž jsou tito součástí. Transverzální propojení (přes hranice teritorií, náboženství, symbolů, kultur i politik) vytvárí koherentní a pro transmigranty významné sociální pole (Hannerz 1998: 240). Jak ukázala Werbner (1990b) a řada dalších autorů, transnacionální sociální prostor je tmelen prostřednictvím sociálních institucí, jakými jsou dary, remitance či transnacionálně uzavírané sňatky (Charlsley 2006, Werbner 1990b). Transnacionální sociální pole lze proto nahlížet jako sociální sféru sui generis, tedy jako sféru, která představuje samostatný „výzkumný terén“ (Amit 2000).

Většina transnacionálních výzkumů i teoretických reflexí transnacionalismu věnovala pozornost primárně transmigrantům a jejich interakcím. Tomu, jakým způsobem konstruují své přináležení $k$, a jak se angažují $v$ mikrosvětech ukotvených „tam“ i „tady“. Jinými slovy, jak transmigranté participují v procesu transnacionální migrace, $\mathrm{v}$ transnacionálním sociálním poli (Szaló 2007: 7).

Studium transnacionální migrace osvětluje formy vazeb, které si transmigranté udržují $\mathrm{s}$ ostatními body v transnacionální síti. Vrátíme-li se ke zhuštěné definici Werbner, vystihuje tato pohyb mezi místy. Nemusí se ale vždy nutně jednat o fyzický pohyb v prostoru (Bos 2006, Eriksen 2006, Szaló 2006). Přesto otázka, kdo jsou ti, kteří jsou rovněž součástí transnacionálních sítí, kteří však zůstali a/nebo byli ponecháni ${ }^{1}$ na druhém

V textu rozlišuji nemigranty na ty, kteří zůstali (have stayed), a ty, kteří byli ponecháni (have been left behind). Tato sémantická distinkce vystihuje postavení a možnosti jednání aktérů na druhém 
břehu, nebyla doposud v rámci transnacionální antropologie systematicky a významněji studována. ${ }^{2}$

V tomto textu je druhý břeh metaforou, jejímž prostřednictvím usiluji nahlédnout transnacionalismus z pohledu „tam“. Jedná se o lokality, které jsou pro transmigranty místem návratu a/nebo přináležení. Transnacionální sociální sítě inherentně rýsují novou kartografii dnešního světa a ovlivňují glokalizaci druhých břehi̊. Pohledem z druhého břehu lze nahlédnout procesy a způsoby formování a vyjednávání vztahů mezi místem, kulturou, pamětí, etnicitou a genderem v transnacionálních sítích (Gardner a Grillo 2002: 180). Tím lze osvětlit dopad současných procesů globalizace na glokalizované komunity, jakkoli situované na druhém břehu.

Na základě re-interpretace několika výzkumů (Gardner 1995, Gardner 1999, Salih 2002), včetně vlastního terénního výzkumu, který mapoval transnacionální sít Česká republika - Rusko - Dagestán, se pokouším o (re)konstrukci pohledu na transnacionální migraci z perspektivy aktérů, kteř́ zůstali/byli ponecháni na druhém břehu (the Rest). Neusiluji primárně o studium transnacionálního sociálního pole. Zaměřuji se na studium transnacionálních sociálních sítí v perspektivě, která zvýznamňuje druhý břeh, doposud přehlíženou součást transnacionálních studií (k distinkci pole-sít’ srov. Szaló 2007: 105-114). Dále nastiňuji dynamiku sociální změny glokálních prostředí v důsledku transnacionální migrace a to, jak jsou $\mathrm{v}$ těchto místech pod vlivem transnacionální migrace ustavovány a vyjednávány nové diference a nerovnosti.

\section{Cesty na druhý břeh}

Navzdory intenzitě transnacionálních praktik, které jim dávají jistý druh stálého členství v Maroku, migranti si udržují nejednoznačný status insiderů/outsiderů v jejich původní společnosti. (Salih 2002: 227)

Salih (2002) studovala cesty na druhý břeh z pohledu transmigrantek. Ve svém výzkumu se zaměřovala na opakované návraty marockých transmigrantek žijících v Itálii zpět do Maroka. Důvodem cest na druhý břeh byla primárně účast na místních rituálech spjatých s životním cyklem (svatby, pohřby, obřízka). Periodické návraty transmigrantek do Maroka nazvala Salih transnacionálni dělbou rituálního prostoru. Vyjadřuje tím, že „,migranti operují v transnacionální dělbě rituálního prostoru, což zahrnuje distribuci symbolických a ekonomických zdrojů např́ič zeměmi skrze praktiky, které konstruují Maroko a Itálii jako klíčové v kulturní a politické ekonomii života migrantů současně“ (Salih 2002: 222). Na prríkladu chlapecké obř́zky ukazuje, že ačkoli byl malý chlapec obřezán v Evropě, teprve o dva roky později, kdy spolu s rodinou navštívil Maroko, došlo k náboženskému rituálu obřízky. Samotný akt obřízky byl nyní pouze „fiktivní“ a představovaný - avšak na performativní a významové rovině byl pro všechny účastníky skutečný.

břehu. Rozsah studie neumožňuje hlubší interpretaci těchto rozdílů v transnacionálních studiích běžně nereflektovaný (např. Gardner 2008).

2 Srov. Gardner (1993, 1995, 1999), Levitt (2001), Taylor, Singh and Booth (2007). 
Náboženskou sféru z pohledu druhého břehu studovala Gardner (1999). Popisuje, jak začal být lokálně konceptualizovaný islám v Sylhet pod vlivem transnacionální migrace vnímán jako periferní a méně ortodoxní a jak došlo k jeho postupnému přehodnocení. Gardner tento proces přehodnocování náboženských významů i náboženské každodennosti a praxe interpretuje jako důsledek transformace sociálních hierarchií a mocenských vztahů v Sylhet. Transnacionální migranti a jejich rodiny žijící v Sylhet získali ekonomický kapitál, který jim umožnil přístup k půdě. A vlastnictví půdy generuje v Sylhet moc (Gardner 1999: 44-45). ${ }^{3}$ Klíčovým aktérem změn v náboženské sféře byli transnacionální migranti, kteří se vraceli z oblastí Perského zálivu zpět do Sylhet. ${ }^{4}$ Jednalo se o rodiny, které svým pobytem v Perském zálivu ekonomicky zbohatly, ale zároveň se vlivem tamního prostředí začaly sebeidentifikovat primárně jako muslimové přináležející k deteritorializované náboženské Ummě (bidesh) a ne k lokalitě - desh (Sylhet). Pro tyto transmigranty a jejich rodiny byla produkce významu toho, co znamená být muslimem a co znamená islám, postupně vymístěna z lokálního kontextu. Přehodnocení náboženských hranic v Sylhet vlivem migrace nazývá Gardner „novou geografií islámu“ (1999: 41).

Asad (1986) popisuje islám jako soubor diskursů, které usilují o to, definovat a kontrolovat ortodoxii i ortopraxi, které jsou ovšem vždy lokalizované. Proto je nutné sledovat způsoby a praktiky, kterými jsou tyto diskursy autorizovány v historickém, politickém a sociálním kontextu (srov. Holy 1988, Rasanayagam 2006). Jak popisuje Gardner, transmigranti a jejich rodiny na druhém břehu, které získaly díky ekonomickému kapitálu půdu a moc v Sylhet, vymístily kontext ortodoxie a ortopraxe mimo Sylhet. Rodiny, které nemají přístup do těchto sociálních sítí, ztratily vliv podílet se na vyjednávání, co je islám, a jejich náboženská praxe se stala periferní, ne-li stigmatizující (Gardner 1999: 38). Gardner upozorňuje na protichůdné významy toho, co je desh pro transmigranty a jejich rodiny na jedné straně, a toho, jaký význam má pro ty rodiny, které byly ponechány na druhém břehu, na straně druhé (srov. Gardner 1993, 1995, Callan 2007).

$\mathrm{Z}$ pohledu religiozity je desh pro transmigranty náboženskou periferií. Avšak viděno z druhého břehu, význam desh je poněkud odlišný. Desh je zemí svatých, která je lidmi z druhého břehu zároveň často popisována jako místo utrpení, chudoby a touhy (Gardner 1999: 46). Bidesh, deteritorializovaná cizina, se v lokálním náboženském životě v Sylhet stala hegemonní, metaforicky i fakticky. Islám v perspektivě desh je součástí „eklekticismu Indického poloostrova“ (Carrithers 2000b: 833) a je ustavován místní synkretickou praxí, která je v rozporu s náboženskou rigorózností ortodoxie lokalizované směrem k deteritorializované Ummě (bidesh). Posun v percepci islámu je umocňován tím, že rodiny s př́stupem k (transnacionálnímu) kapitálu a hodnotám bidesh si mohou dovolit posílat své syny do

3 Tento argument lze ilustrovat nedávným výzkumem ze Sylhet, prováděný v lokalitě Jalalgon, kde transmigranti a jejich př́ibuzní vlastní 85,9 \% veškeré půdy (Gardner and Ahmed 2006: 13).

4 Ačkoliv $95 \%$ bangladéšské populace žijící na území Velké Británie je původem ze Sylhet, současný tok migrace ze Sylhet směřuje primárně do zemí Perského zálivu. To je mimo jiné způsobeno právními omezeními ze strany Velké Británie a jediná cesta, jak se v současnosti dostat z Bangladéše do Velké Británie, je skrze sňatek s britským občanem. Místní termín pro Bangladéšany s britským občanstvím je „Londoni“ (Callan 2007). 
náboženských škol (madrás). Tito mohou po svém návratu skrze mocenské hierarchie a kontrolu „správného islámu“ postupně nahrazovat tradiční náboženské autority, jakou jsou súfijští duchovní (pirové), což je v posledních letech dále umocňováno tím, jaký důraz začal být kladen na vykonání hadže - pouti do Mekky. Naproti tomu pirové v duchu místní synkretické praxe „nabízejí“ sedm poutí do Ajmir v Indii jako ekvivalent vykonání hadže (Gardner 1999: 41). Tato alternativa je v současném Sylhet nahlížena nejen jako ne-islámská, ale rovněž jako strategie chudých. Samotná pout' do Mekky je finančně velmi nákladná a málokdo v Sylhet si ji může dovolit. Postupně sílící vliv duchovních vzdělaných v madrásách, umocněný kontinuální transnacionální migrací zapříčinil, že se tato náboženská praxe postupně stává v Sylhet dominantní, a proto i exkludující normou posuzující „správné muslimstvi““.

Jiným př́kladem cesty na druhý břeh je svatební rituál. Salih přesvědčivě ukazuje, jak řada transmigrantek využívá tradičně organizovaných svateb v Maroku k performanci a následnému zisku hierarchicky vyššího statusu prostřednictvím módního italského oblečení a šperků (a to bez ohledu na svůj sociální status v Itálii). Avšak vždy v kombinaci s nošením „tradičního“ bílého hidžábu. Jak je patrné, transnacionální dělba rituálního prostoru a rituál samotný se stávají místem střetu a vyjednávání o zachování lokálního řádu a/ nebo o jeho změně. Salih tím dokládá, jak je problematické stavět ostré hranice mezi tradičním a moderním, lokálním a globálním. Zároveň tím odhaluje ambivalentní povahu života marockých transmigrantek: „usilují o přináležení a zároveň o vymezení se“ (Salih 2002: 229). Její výzkum lze číst jako př́ípadovou studii toho, jak jsou transnacionální sitě propojeny s lokální mikro-politikou a nakolik jsou nedílnou součástí produkce významů lokální socio-kulturní sféry.

Uvedené př́íklady dokládají, že angažování se $\mathrm{v}$ transnacionálních sítích je životem „mezi“ (betwix and between), který může mít formu (1) tady i tam, nebo (2) ani tady, ani tam (Grillo 2001: 17-20). Jaký je ale pohled $z$ druhého břehu? Jedním z možných způsobů, jak nahlédnout tuto odlišnou perspektivu, je zaměřit pozornost na hierarchizovanou ekonomii darování, respektive na symbolickou ekonomii, která se váže k cestám na druhý břeh.

Cesta transmigrantů na druhý břeh je nevyhnutelně spjata s ekonomií daru (Salih 2002; Werbner 1990a, 1990b, 2005). Werbner, Salih a další autoři ukázali, jak (1) samotná volba darů při př́pravách cesty na druhý břeh zhmotňuje představy a očekávání transmigrantů o tom, co je reprezentací „Západu“; a že (2) dávání darů je aktem hierarchizované ekonomie darování, nebot' ekvivalentní oplátka je mnohdy ze strany obdarovaného (the Rest) nemožná. Tato ne-možnost oplátky vráží klín do řetězce darovat-přijmout-oplatit, do logiky daru (Mauss 1999), a tím může vést k symbolické dominanci (Bourdieu 1990). Nemusí tomu tak být ovšem vždy. Jak uvádí Bourdieu (1990: 98), dar může zůstat neoplacen, není-li závazek oboustranně uznán. Dar může být rovněž odmítnut jako akt potupy. Podobně Laidlow (2000) ukázal, jak v př́ípadě obdarovávání žijících světců a mnichů v Indii mohou být kategorie „dávající“ a „přijímající“ zcela obráceny, respektive jsou kontextuálně manipulovány v závislosti na statusu a prestiži aktérů daného dyadického vztahu. 


\section{Rituál, performance a symbolická dominance: transnacionalismus v jižním Dagestánu}

Pokud je zahrnutí do transnacionálních sítích za hranicí možností některých jedinců, obvyklým důsledkem je, že se transnacionalismus stává vektorem, skrze nejž získává stratifikace svou podobu a způsob svého vyjádření. Zatímco transnacionální rituály mohou symbolicky vyjadřovat sounáležitost, realita je taková, že lidé jsou fyzicky odděleni. (Gardner a Grillo 2002: 184)

V jižním Dagestánu, kde jsem prováděl terénní výzkum, tvořili více než polovinu obyvatel vesnice transmigranti, kteří se periodicky vraceli zpět domů pouze v letním období a v období Ramadánu. ${ }^{5}$ Hlavním důvodem cesty na druhý břeh byla účast na rituálech životního cyklu, především účast na svatebních rituálech. Naprostá většina transmigrantů, kteří se vracejí do vesnice, žije a pracuje v Moskvě a Sankt-Petěrburgu. Tato dvě místa zastupují v lokálních významech a diskursech the West. Jsou přesvědčivou metaforou (Fernandez 1986), která rozděluje osoby, prostor i věci na tady a tam, což bylo zvýznamněno i během svatebních rituálů. V této studii vycházím z pojetí rituálu jako účelové a expresivní ceremoniální performance, která slouží k oslavě životních událostí nebo krizí (srov. Gardner a Grillo 2002: 183). V kontextu cest na druhý břeh navrhuji nahlížet rituály životního cyklu ve dvou vzájemně provázaných rovinách: (1) rovina performativní, (2) rovina, na níž jsou vyjednávány odlišnosti a mocenské vztahy.

Performativní rovinu rituálu představil Schieffelin (1985). Performance, tedy sociální konstrukce situace, umožňuje účastníkům rituálu zakoušet symbolické významy ted' a tady (Schieffelin 1985: 709). Důraz na sociální aspekt, tedy na intersubjektivně ustavovaný význam situace, je podstatný. Na performativní rovině rituálu jsou významy nastolovány a/nebo (re)formulovány. Svatební rituály jsou procesem performance par excellence. Výše jsem představil svatební rituál popsaný Salih (2002), kdy sociální konstrukce situace, na které participovaly i transmigrantky, vedla k redefinování symbolů, významů a jednání spjatých s místní svatbou (kombinace módního italského oblečení s tradičním bílým hidžábem).

Rovinu komunikace a vyjednávání odlišností a mocenských vztahů představil Baumann (1992), který tvrdí, že sociální vědci mají tendenci nahlížet rituály jako místo sdílení vztahů, performancí, symbolů a jejich významů (Baumann 1992: 98). Oproti této optice nabízí Baumann odlišný pohled, $v$ němž je rituál jakousi konfliktní arénou mezi soupeřícími stoupenci: „namísto logiky reprodukování a udržování společenských hodnot [...] mohou rituály rovněž vypovídat o aspiracích směřujících ke kulturní změně“ (Baumann 1992: 99). Nahlédnuto touto optikou, cesta na druhý břeh nevede nutně k re-integraci a ke znovu-sjednocování lokálních komunit a rodin ani k ustavování a stmelování transnacionálních sociálních polí. Skrze transnacionální dělbu rituálního prostoru, která je lokalizována směrem na

\footnotetext{
V letech 2006-2007 jsem prováděl výzkum zaměřený na studium transnacionálních sociálních sítí muslimů žijících v České republice. V červenci-srpnu 2007 jsem v tomto výzkumu pokračoval, kdy jsem na šest týdnů následoval jednu z rodin žijící v České republice na druhý breh, do Moskvy a do jižního Dagestánu.
} 
druhý břeh, dochází $\mathrm{k}$ ustavování a ritualizaci nových hierarchií a odlišností v glokalizovaných sociálních polích na druhém břehu. Podle Baumanna (1992: 113) „definice ,my“ a ,oni“ není pouze kontextuální, ale vnitřně dialektická a tato dialektika může být zdrojem samotného rituálu“. V rituálech, které se váží k cestě na druhý břeh, se ustavují odlišnosti a hierarchie mezi transmigranty a těmi, kteří zůstali/byli ponecháni (srov. Salih 2002: 223).

Pro další ilustraci tohoto argumentu uvádím př́klady trrí svateb, které se konaly v rozmezí jednoho roku $\mathrm{v}$ rámci jedné príbuzenské sítě v Dagestánu. Během mého pobytu ve vesnici se v jednom týdnu uskutečnily dvě z těchto svateb (rodina Šamila a Rumika). Třetí svatbu (rodina Mehmeda) jsem re-konstruoval kombinací polo-strukturovaných rozhovorů a audio-vizuálních dat, kdy jsem měl $\mathrm{k}$ dispozici pět hodin filmového materiálu a více než 100 fotografií (srov. Banks 2001).

Rodina Šamila výrazně participuje $\mathrm{v}$ transanacionálních sítích. Část rodiny pracuje a dlouhodobě žije v Moskvě a pravidelně se vrací do vesnice pouze v letních měsících. Šamilova rodina se rozhodla během letních měsíců, kdy se vrací do Dagestánu, uspořádat svatbu Šamilova syna v této vesnici, a to i presto, že oba snoubenci žijí v Moskvě. Oba však mají rodiny a vazby na stejný region v Dagestánu. V kontextu místní ekonomie patří Šamilova rodina mezi úspěšné, disponující dostatečným kapitálem na to, aby si mohla dovolit uspořádat okázalou svatbu: konstruovat situaci (svatební rituál) způsobem, který tento ekonomický úspěch potvrdí. Ta část rodiny, která je tvořena transmigranty, tak získala př́iležitost sebe-prezentace jako úspěšných transmigrantů. Č́st rodiny, která i nadále žije ve vesnici, využila konstrukce situace $\mathrm{k}$ vyjednávání mocenských vztahů ve vesnici. K prípravám a organizaci svatebního rituálu samotného využila Šamilova rodina kombinaci (transnacionálního) kapitálu a sousedských př́buzenských sítí ve vesnici. Pro př́ípravu jídla, pro více než 250 hostů, si však rodina najala tři profesionální kuchaře. To bylo poněkud neobvyklé, nebot' obvyklým způsobem je, že o př́pravu jídla se starají výhradně ženy, koordinovány matkou ženicha. Dále si Šamilova rodina najala hudební skupinu, která nebyla ze stejného regionu, kde se nachází vesnice (u hranic s Ázerbajdžánem), ale z hlavního města (Machačkala). Tato hudební skupina pak po celou dobu hrála, slovy samotných aktérů, „,moderní popovou dagestánskou hudbu“".

Rodina Rumika př́mo neparticipuje na transnacionálních sítích. Rumik a jeho dva synové jsou nezaměstnaní, jeho manželka i manželka nejstaršího syna jsou v domácnosti. Třetí syn žije v České republice, ale remitance neposílá. Rumikova rodina se rozhodla uspořádat svatbu nejmladšího syna $v$ letních měsících, kdy spolu se svou rodinou prrijel i syn žijící v České republice. Nevěsta byla ze stejné vesnice, avšak její otec pracuje v Sankt-Petěrburgu. Tento fakt nicméně neměl vliv na organizaci svatby samotné, která byla dle místních zvyklostí organizována a financována výhradně rodinou ženicha a rodina nevěsty se svatebního rituálu ani neúčastnila. Rumikova rodina patří mezi rodiny ekonomicky neúspěšné, neparticipující na transnacionální migraci. Sám Rumik je od doby rozpadu Sovětského svazu na počátku devadesátých let nezaměstnaný. Při př́ípravách na svatební rituál a během rituálu samotného využila rodina především sousedských vazeb založených na kooperaci a reciprocitě a také př́buzenských vazeb. Veškeré př́ípravy jídla byly koordinovány Rumikovou ženou a jejími sestrami. Na svatbu byla najata hudební skupina z blízkého města, která hrála místní tradiční hudbu. Samotného svatebního rituálu se účastnila přibližně stovka hostů. Je 
důležité rovněž zmínit, že se rodina kvůli svatbě zadlužila, v očekávání, že se jí náklady na svatbu vrátí ve formě finančních darů, což se nestalo. ${ }^{6}$

Již z krátkého popisu organizace svatebních rituálů rodiny Šamila a Rumika vystupují rozdíly a ohniska možného napětí na druhém břehu. To je navíc umocňováno faktem, že konkrétně tyto dvě rodiny sdílejí místo residence: jedná se o dva domy stojící na společném pozemku, se společným dvorem, zahradou a vodovodem. To, že se nejedná o rozdíl „tradiční“ versus „moderni'“ svatební rituál (srov. Salih 2002), vyplývá z porovnání s okázalým způsobem, jakým o rok dříve organizovala svatební rituál rodina Mehmeda. Mehmed a celá jeho rodina žijí a pracují v Moskvě. Ve vesnici mají i nadále dům, ale nikdo v něm během roku, kdy je rodina v Moskvě, nežije. Vzhledem k tomu, že sám Mehmed, jeho manželka i synové v Moskvě pracují, patří mezi ekonomicky úspěšné transmigranty. Přestože rodina žije v Moskvě, rozhodl se Mehmed uspořádat svatbu svého syna v jižním Dagestánu. Avšak ne ve vesnici, jako rodiny Šamila a Rumika, ale v osmdesát kilometrů vzdáleném městě, kde pronajal hotel a zaplatil a organizoval převoz hostů z vesnice do hotelu a pro novomanžele navíc pronajal limuzínu. Samotná svatba byla organizována najatou svatební agenturou z hlavního města, což svatební rituál zcela vyvázalo z lokálních zvyklostí.

Pro tuto chvíli jsou naznačené rozdíly ve způsobu organizace svateb rodiny Šamila, Rumika a Mehmeda, kteří jsou součástí jedné prríbuzenské sítě (všichni tři jsou si vzájemně bratranci z otcovy strany), dostatečné k interpretaci toho, co Schieffelin nazval konstrukcí situace. Tedy intersubjektivně konstituovaného významu situace - performance. Jak poznamenala Argyrou (1996), svatební rituály v regionálním kontextu Středomoří a Malé Asie jsou charakteristické vysoce okázalou spotřebou a soupeřivou symbolickou směnou, která je v mnohém homologická s potlachem Kwakiutlů. Proto o svatebních obřadech hovoří jako o symbolickém zápasu mezi jednotlivci, domácnostmi a rodinami.

Pro rodinu Rumika byla účast v procesu symbolické směny během svatebního rituálu obtížná, nebot' byla posuzována a interpretována ve vztahu ke svatbám rodiny Šamila a Mehmeda. Rumikova rodina nebyla schopna ekvivalentní symbolické směny. Neschopnost ekvivalentní směny byla lidmi ve vesnici interpretována v pojmech ekonomického ne/úspěchu, který plynul z ne/participace $\mathrm{v}$ transnacionálních sítích. Vyjádřeno v pojmech, které užívá Argyrou (1996), Rumikova rodina byla v této soutěživé symbolické směně poražena. Tato porážka však měla konkrétní důsledky. V posledních několika letech probíhá mezi těmito třemi rodinami pře o vlastnictví půdy, a i díky této symbolické porážce, která je symbolickým vyjádřením a potvrzením neúspěchu, je rodina Rumika z dalšího průběhu vyjednávání o vlastnictví půdy de facto vyloučena.

Jak jsem ale uvedl v úvodu tohoto textu, usiluji o to nastínit pohled $z$ druhého břehu. Rituály životního cyklu, jakým je i svatba, jsou místem, kde jsou vyjednávány mocenské a genderové vztahy a identity. Vrat'me se ke slovům Baumanna (1992: 113): „definice ,my“ a ,oni“ není pouze kontextuální, ale vnitřně dialektická a tato dialektika může být zdrojem samotného rituálu.“ Proto rozdíly ve způsobech organizace svateb vedly nevyhnutelně k odlišným způsobům konstruování sociálních identit účastníků těchto svatebních rituálů.

6 Podle mých výpočtů se pohybovaly náklady na svatbu Rumikova syna v přepočtu kolem částky 220000 korun. 
V průběhu svateb rodin Šamila a Rumika i po nich jsem uskutečnil řadu polo-strukturovaných rozhovorů. $Z$ nich vyplynulo ono vnitřně dialektické napětí, o kterém hovoří Baumann.

Ti aktéri, které lze označit za ekonomicky úspěšné, z nichž je naprostá většina aktivní v transnacionálních sítích, neviděli nic problematického ve způsobu, jakým rodina Šamila organizovala svatbu. O svatbě Mehmedova syna dokonce hovořili jako o určitém ideálu svateb do budoucna. Naopak svatbu Rumikova syna hodnotili jako zaostalou a jeho rodinu jako chudou. Tento pohled lze navíc dokreslit jedním z výrokủ, který na Rumikovu adresu zazněl: „je překvapením, že si během svatby nevystačili s rajčaty a chlebem“.7 Podobnými výpověd’mi lidé ve vesnici nenaráželi pouze na rodinu Rumika, ale na celkový posun ve vnímání vztahů a hodnot ve vesnici: sociální topologie vesnice se nyní v jejich optice dělila na sociální sítě úspěšných/neúspěšných, na bohaté/chudé, na moderní/zaostalé a tak dál. Jaký je ale pohled $z$ druhého břehu? Jaký je pohled Rumika a těch, kteř́ zůstali? Nejedná se o konsensuální pohled, ale ani ne o pohled pouze dialekticky obrácený. Je to pohled jiný.

Rumik a další lidé $\mathrm{z}$ vesnice, s nimiž jsem měl možnost hovořit, vysvětlovali rozdíly ve způsobu organizace svateb smirŕlivěji. Když se sešlo několik starších mužů den po svatbě Rumikova syna, shodli se na tom, že „taková svatba, jakou organizoval Šamil, je dneska $v$ Moskvě normální". Tímto výrokem vyjádřili a načrtli hranice mezi vesnicí a Moskvou a rodinu Šamila přesunuli na moskevskou stranu. Nejvíce diskutované však byly rozdíly v hudbě, která se během jednotlivých svateb hrála. Hudební a taneční performance tvoří v tomto dagestánském regionu velmi podstatnou část svatebního rituálu. Odlišnost narušuje možnost intersubjektivního sdílení, a tím i spolu-identifikace a přináležení. Sám Rumik k rozdílům v hudbě opakovaně dodával, „toto není naše hudba“. Čí to tedy byla hudba? Dřive, než se pokusím odpovědět, chtěl bych na okamžik zvýznamnit to, co lze označit jako figurativní způsob myšlení (srov. Carrithers 2008, Fernandez 1986). Tento způsob myšlení je v první instanci kognitivním pohybem, který následně vede $\mathrm{k}$ (rétorické) performanci: užití zájmena „naše“ nevyhnutelně vede $\mathrm{k}$ dichotomické konceptualizaci celé události, která v daném př́padě rozděluje participanty svatebního rituálu na „my“ a „oni“. Čí to tedy byla hudba? Byla to jejich hudba. Rumik a další lidé z vesnice dávali smysl celé události (svatbě) prostřednictvím rétorických figur „naše“, ,jejich“, „,oni“, „my“ a tak dál. Taková konceptualizace rýsuje imanentně hranice mezi jednotlivými aktéry, vnímanými jako Nebenmenschen/Mitmenschen, použijeme-li Schützovy terminologie (srov. Schütz 1967). Tedy mezi těmi, kteří jsou součástí „našeho“ životního světa (Lebenswelt), a mezi těmi, kteří se v něm stali cizinci, a to bez ohledu na to, zdali sdílejí stejnou príbuzenskou sít'.

Je zřejmé, že (ne)participace $\mathrm{v}$ transnacionálních sítích akceleruje na druhém břehu pnutí v rodinných, ale i místních veřejných sítích a solidaritě. ${ }^{8}$ Veřejné události, jako je svatba, právě pro svůj performativní charakter vtahují do vyjednávání mimo-rodinné aktéry. Jak vyplývá z citátu v úvodu této kapitoly, cesty transmigrantů na druhý břeh mohou vybízet

7 V letních měsících jsou rajčata jednou z nejlevnějších potravin. Kupují se po 20 a více kilogramech. Rumikova rodina navíc rajčata pěstuje na své zahradě. Řada rodin ve vesnici rovněž nekupuje chléb, ale peče si vlastní chléb doma. Tak tomu bylo i v př́ipadě Rumikovy rodiny.

8 Tím mám na mysli tu oblast společenského života, kterou Rasanayagam (2002) označil jako sféru komunální participace. 
k durkheimovské perspektivě re-integrace komunit, vesnických či rodinných, a to především během rituálů. Avšak studiem performativní roviny rituálů, která odkrývá, jak je konstruována a vyjednávána sociální komunikace mezi transmigranty a aktéry z druhého břehu, se může vyjevit i odlišný ,př́íběh“.

\section{Sociální změna}

Transnacionalismus může rozdělovat a stejně tak i sjednocovat transnacionální komunity a současně vytvářet a reprodukovat formy sociální nerovnosti a sociální rozdílnosti např́íc národními hranicemi. (Taylor, Singh a Booth 2007: 343)

V předcházejících kapitolách jsem naznačil kontrastní pohledy cesty na druhý břeh. V celém textu jsem však latentně diskutoval vztah mezi místem, sociální změnou a transnacionální migrací. Tento vztah byl často studován v ekonomizující perspektivě jako dopad remitancí. Snažil jsem se ukázat, jak jej lze studovat i na jiných úrovních. Např́klad ve snaze zjistit, jak jsou produkovány nové nerovnosti, sociální napětí a odlišná dynamika sociálních změn.

Levitt (2001) studovala transnacionální sociální sítě na ose Mexiko - USA, které bývají často brány jako učebnicový př́klad transnacionální migrace. Ukazuje, jak pohyb lidí, kapitálu i myšlenek vede nejen k propojovaní míst a vytváření hybridních sociálních polí, ale i ke změnám v místech na druhém břehu. Symbolický, ekonomický i sociální kapitál, který proudí v transnacionálních sítích a je i agentem změny, však musí „,být kontextualizován V rámci partikulárních geografií moci a praxe“ (Gardner a Ahmed 2006: 5). Levitt ukazuje, že v př́padě Mexika vedlo propojení druhého břehu a transnacionálních sítí často ke komunálnímu socio-ekonomickému rozvoji. Nejednalo se však o spontánní proces. V současnosti je tento proces kontrolován jak rozvojovými agenturami, tak i politicky. Nadto může využívání transnacionálních sítí ke komunálnímu rozvoji druhého brehu nacházet podporu v lokálních morálních kategoriích. V případě Mexika se jedná o politický apel na kolektivní participaci, tedy zpětné investování kapitálu a zasílání remitancí do Mexika. Tato politická rétorika do značné míry využívá idealizovaný obraz místní sociální organizace - egalitárních rolnických komunit (srov. Kearney 1996).

V oblastech Středomoří a Středního východu, kam lze zařadit Dagestán, Maroko i Bangladéš, jsou místní morální kategorie i sociální organizace charakteristické asymetrickými sociálními vztahy, které bývají označovány jako vztahy patron-klient (Boissevain 1966, Cambell 1964, Lyon 2004). Proto v těchto oblastech generují transnacionální sítě často konfliktní dynamiku sociální změny. A to tím, že proudění symbolického, sociálního i ekonomického kapitálu $\mathrm{v}$ transnacionálních sítích proměňuje mocenské vztahy a re-definuje tradiční morální kategorie i sociální organizaci. Tradiční lokální autority (pirové a majitelé půdy) jsou nuceni re-definovat svou legitimitu ve vztahu k autoritám novým, které ustavují svou moc prostřednictvím inkluze do transnacionálních sítí. ${ }^{9}$ Avšak třetím aktérem této změny jsou lidé z druhého břehu, z transnacionálních sítí vyloučení. Pro ně je druhý břeh

9 Lyon (osobní komunikace) během terénního výzkumu v pákistánském Paňdžábu zaznamenal, že někteří z místních bohatých majitelů půdy (tzn. patronů), kteří vlivem př́livu transnacionálního 
posvátnou zemí předků, ale také místem utrpení, chudoby a touhy (srov. Gardner 1999: 46). Formování transnacionálních sítí a možnost participace v nich je tak imanentně jak procesem inkluze, tak i exkluze. V Dagestánu se vyloučení z transnacionálních sítí projevovalo nejzřetelněji ve třech oblastech každodenního života: (1) v rozdílech v kvalitě bydlení, (2) v rozdílném přístupu $\mathrm{k}$ pitné vodě, (3) v rozdílech $\mathrm{v}$ př́istupu $\mathrm{k}$ lékařské péči.

$\mathrm{V}$ místě, kde jsem prováděl terénní výzkum, byla $\mathrm{v}$ posledních letech postavena řada nových domů. Výstavba všech nových domů byla financována transnacionálním kapitálem, který proudil z Moskvy, Sankt-Petěrburgu a v několika př́padech i ze Spojených arabských emirátů. Způsob výstavby nových domů symbolizoval nové diference a hierarchie. Okázalé nové domy nebo okázalá rekonstrukce starších domů jsou ve vesnici vnímány především jako symbolické vyjádření úspěchu, respektive neúspěchu. K podobným trendům dochází i v Pákistánu, Indii či Bangladéši (srov. Gardner 2008; Gardner a Ahmed 2006; Taylor, Singh a Booth 2007). Ke kvalitě bydlení se váže i rozdílný přístup k pitné vodě. Pouze ekonomicky úspěšné rodiny, ve většině prrípadů napojené na transnacionální sítě, si mohly dovolit přívod vody až do svých domácností, potažmo její skladování v zásobnících. Nadto jedna z rodin v místě mého výzkumu získala díky remitancím značný kapitál a financovala výstavbu nové veřejné pumpy ve středu vesnice. Na její výstavbu, jak sami lidé z vesnice často upozorňovali, bylo použito místního kamene, což zdůrazňovalo vazbu rodiny na místo, umocněnou vytesanými portréty zesnulých prarodičů, kteří ve vesnici žili a jsou zde i pochováni. Rodina, která financovala vybudování této pumpy, nepatřila mezi tradiční autority, avšak nyní získala významnější postavení, které dosud neměla. Chudé rodiny bez vazeb na transnacionální sítě a kapitál jsou nuceny chodit pro vodu $\mathrm{k}$ této pumpě, která přestala být vnímána jako veřejný zdroj vody a je chápána jako pumpa rodiny, jež financovala její vybudování. V daném případě se nejedná o př́mý vztah patron-klient, ale o ustavování jiných forem dominance, které však fungují na podobném principu asymetrického vztahu.

Gardner a Ahmed (2006) studovali podobné vztahy i v Bangladéši. Lidé vyloučení z transnacionálních sítí a bez vlastnictví dostatečného kapitálu mohou do těchto sítí vstupovat pouze skrze kvazi-klientské vztahy. Jak jsem naznačil, skrze transnacionální sítě se mohou ustavovat nové formy dominance a protekcionismu, které v mnohém kopírují logiku vztahu patron-klient. Během mého výzkumu se tento druh sociálního protekcionismu projevoval v rozdílném přístupu k lékařské péči. Jedna z rodin musela velmi složitě vyjednávat pomoc, aby zajistila specializovanou operaci srdce svého pětiletého syna v Moskvě. Kromě finanční pomoci, která by pokryla náklady spojené s operací, potřebovala tato rodina zajistit i dopravu do Moskvy a ubytování zde. Po několikatýdenním vyjednávání se podařilo dohodnout „pomoc“ od jedné z místních rodin, která dlouhodobě pobývá v Moskvě a do vesnice v Dagestánu se periodicky vrací pouze v letních měsících a v měsíci Ramadánu. Rodina s nemocným chlapcem se tak napojila na transnacionální sít' tím, že se zavázala, že se bude starat o dům a pozemky rodiny, která zajistila pomoc, v době její nepřítomnosti, a to na neurčitou dobu. To se však ukázalo jako velmi těžko splnitelný závazek, nebot' členové této rodiny dosud veškerý čas věnovali obdělávání vlastních polí a pastvě ovcí, které jsou jejich

kapitálu začali ztrácet svou autoritu, nikoli však majetek, začali posílat své syny studovat na prestižní západní university, a to primárně ze symbolických důvodů. 
jediným zdrojem obživy. Subsistenční aktivity tak museli částečně omezit. V tomto konkrétním případě lze o takovém asymetrickém vztahu a inkluzi v transnacionálních sociálních sítích hovořit jako o perverzním sociálním kapitálu (Gardner a Ahmed 2006: 5).

Taylor a kol. (2007) na základě studia dopadů transnacionální migrace na oblast severního Paňdžábu ukazují, že remitance směřované na druhý břeh nevedou ke komunálnímu rozvoji, ale jsou zacílené pouze na vybrané rodiny. Jedná se o rodiny, které byly tradičně bohaté, proto měly v minulosti kapitál umožňující financovat migraci do ciziny. V místech s výraznými asymetrickými sociálními vztahy, jako je Pákistán, Bangladéš nebo Dagestán, nemusí vést napojení na transnacionální sítě ke komunálnímu rozvoji. Jak konstatuje Taylor a kol. (2007: 339), nerovnosti zůstávají, změnil se pouze způsob jejich (re)produkce.

Netvrdím však, že by druhý břeh byl fixovaný v neměnném stavu, který se proměnil vlivem transnacionální migrace. Sociální realita každodenního života v Brně, Mexiku i Pákistánu je v neustálém pohybu vzájemných akcí, reakcí a možností, jež přispívají k intersubjektivně vytvářené a sdílené zkušenosti. Nadto samotné mocenské vztahy procházejí v místech, jako je Pákistán, Bangladéš či Dagestán, neustálou změnou, která je často ovlivněna vývojovým cyklem rodin, soupeřením vlastníků půdy mezi sebou, ale i působením řady politik (regionálních, státních i nevládních). O co usiluji, je upozornit na odlišné formy sociální změny a sledovat jejich příčiny a důsledky (Ellen 1994). Což nevyhnutelně vede ke studiu toho, jaký vliv mají transnacionální sítě na různých úrovních: do jaké míry se stávají součástí produkce významů a jak operují „, rámci partikulárních geografií moci a praxe“ (Gardner a Ahmed 2006: 5). Jednou z těchto úrovní, která bývá v transnacionálních výzkumech podceňována, je rovina druhého břehu.

\section{O liškách a ježcích aneb Transnacionalismus a cykličnost antropologické teorie}

A tohle jsou zářivé ježkovské teorie, které vrhají na první pohled silné světlo na lidské záležitosti. Jako všechna zářivá světla, i ony vrhají tmavý stín. Zdalipak všechno významné stojí výlučně na světle? Nebo nás silné světlo pouze oslepuje vůči mnohem důležitějším věcem, které zůstávají v šeru? (Carrithers 2000a: 359)

První genealogický výklad transnacionálního/ch diskurzu/ů představil v českém kontextu Szaló (2007). Vztaženo k transnacionální antropologii, lze jeho výklad doplnit o další rovinu: o otázku cykličnosti antropologické teorie. Tato rovina staví transnacionální antropologii do odlišného světla. V diachronní perspektivě se transnacionální diskurzy formují především po vlně kritické (postmoderní) antropologie a interpretačního obratu v sociálních vědách:

v diskursu kritické antropologie se v osmdesátých letech artikulovalo znepokojení nad tím, že pečlivě a detailně prováděné etnografické výzkumy mikro-světů končí v podobě textů, které staví na interpretacích pracujících s teoretickými pojmy politické ekonomie a strukturálního funkcionalismu, jež byly na poli sociologické teorie dávno zproblematizovány. Právě tato teoretická zakotvenost etnografie současných mikro-světů $\mathrm{v}$ zastaralých makro-pojmech odrážejících představy a projekty minulosti zpochybňuje nárok etnografického výzkumu zobrazovat tyto mikro-světy adekvátně. (Szaló 2007: 98) 
O to pozoruhodnějšś je, že od druhé poloviny devadesátých let lze v rámci transnacionální antropologie pozorovat jistou pojmovou a ideovou cykličnost, obohacenou nyní o rovinu reflexivity: $\mathrm{s}$ větším či menším důrazem dochází v transnacionálně-antropologických výzkumech k návratu ke „klasickým otázkám“ a pojmům, jako jsou domácnost, rodina, gender, př́buzenství a rituál (Al-Ali 2002; Bryceson a Vuorela 2002; Gardner a Grillo 2002; Charlsley 2005, 2006; Charlsley a Shaw 2006; Nielsen 2004). Je možné tedy vznést otázku, zdali díky transnacionální optice nechytá antropologie, po vlně kritické antropologie, svůj druhý dech a nenachází možnost svého znovu-vyjádření v etnografickém studiu (g)lokalizovaných životních světů druhých břehů.

Pokusím se tento argument opsat antickou metaforou o lišce a ježkovi, kterou jsem si vypůjčil od Michaela Carritherse (srov. Carrithers 2000). Antropologie v tom nejobecnějšśm konsensu vyjadřuje úsilí nabízet interpretace na otázky, co znamená být člověkem. Jak ve své universalitě, tak i ve své jedinečnosti. Metafora o lišce a ježkovi vyjadřuje rozdíl v př́istupech k této otázce a v jejích konceptualizacích. Ježek, píše Carrithers, „,,zná jednu velkou věc', tuto mistrovskou distinkci mezi osobností moderního Okcidentu v kontrastu k nějaké jiné (pravděpodobně Jiné) společnosti nebo společnostem“ (Carrithers 2000a: 356). Na druhé straně jsou lišky, které „straší ježky svými detailními empirickými studiemi, tázáním a doplňováním či odmítáním mistrovské distinkce“ (Carrithers 2000a: 357).

Kritická antropologie svými argumenty problematizovala stávající prístupy právě pro jejich za(u)jetí v ,jedné velké věci“. Na druhé straně se tato kritika často odehrávala tout court a chytala se do vlastní pasti, nebot' místo proklamované „multivokality“ byla pouze jinou variantou sebestředného intelektuálního imperialismu (Hastrup 1995). Jak uzavírá Szaló ve svém výkladu transnacionalismu debatu o vztahu kritické antropologie a transnacionálních studií:

I z tohoto důvodu vznikly v rámci antropologie interpretační strategie, podle kterých je relevantnější soustředit zkoumání spíše na transnacionální sociální pole a na kulturní proudění $\mathrm{v}$ jejich rámci než na místní kultury zajímavé pro nás svým exotismem. (2007: 96)

Ve svém textu jsem se snažil ukázat, že vyloučení perspektivy druhého brehu z transnacionálních studií pro svůj „exotismus“ a výlučné zaměření se na jednu rovinu, například pouze na transmigranty a transnacionální sociální pole, může stavět dané výzkumy do pozice ježků. Reflexivním znovu-obrácením se na „malé věci“ každodenního světa života (Lebenswelt) v transnacionálních sociálních sítích lze zahrnout druhý břeh do transnacionálních studií (Callan 2007).

Callan svým výzkumem znovu vnáší otázku lokality a místa. Ukazuje, že lokalismus nelze z výzkumu zcela vypustit či jej ignorovat. Obzvláště je-li součástí místních (emických) výkladů životního světa a důležitým prvkem lokálních kosmologií. Ovšem spíše než a priorní vylučování otázek po lokalitě či místu pro svůj „exotismus“ může být vhodnější následovat Strathern (1984). Strathern navrhuje uvažovat o lokalismu/lokalitě jako o souboru idejí o významnosti místa. Takové vymezení je dostatečně otevřené jak deteritorializaci, tak teritorializaci/lokalizaci, a to $\mathrm{v}$ závislosti na konkrétních výzkumech a otázkách. Tento př́stup není ničím jiným než liščí strategií. Pro deteritorializované transmigranty à la Rushdie lze soubor idejí o významnosti místa vyjádřit př́mo slovy samotného autora; „domov se 
stal v našich současných útrapách tak odtrženým, narušeným, různorodým pojmem! Je toho tolik, po čem lze tesknit“" (Rushdie 1997: 79). Na druhé straně, pro některé rodiny v Dagestánu či pro Sylhet’any vyloučené z transnacionálních sítí může být lokalita velmi konkrétní: každodenní boj s chudobou a utrpením, ale i touhou. Lokalita však může být i místem předků a paměti. Netvrdím, že by aktéři z druhého brehu byli obětí transnacionální migrace nebo pasivním „bodem“ transnacionálních sítí. Druhý břeh není výrazem pasivity, ale je výrazem možných strategií, které mohou daní aktéři využívat a s jejichž pomocí mohou manipulovat ve svém každodenním životě. A tyto možnosti se liší od možností transmigrantů i aktérů z druhého břehu, kteři jsou součástí transnacionálních sítí. Nahlédnout tyto procesy znamená usilovat o studium ,malých věcí“. Reflexivita postmoderní antropologie by měla být v transnacionálních výzkumech prostředkem, nikoli cílem snažení. Jinak riskuje, že namísto vhledu do složitostí dnešního světa bude pouze jinou variantou intelektuálního imperialismu, kterým se přiblíží ve svém úsilí ježkům. Reflexivita by neměla z výzkumů transnacionální migrace vymístit etnografickou senzitivu. Etnografická senzitivita vede k tomu, co Carrithers (2005) nazval angažovaným učením: k otevřenému vztahu založenému na vzájemnosti a reciprocitě. Je to intelektuální i tělesná praxe, která v sobě implicitně zahrnuje morální dimenzi související s uznáním „Druhých“: je uznáním toho, že i druzí mají svou cenu. Toto porozumění se nachází v samotném srdci etnografického projektu. Etnografie je závislá na vytváření vztahi̊ $s$ lidmi, není to čistě utilitární aktivita. Úspěšnost celého počínání je odvozena mnohem více od toho, co se antropolog naučil o lokálních morálních standardech díky těmto vztahům, než od toho, co nasbíral (pouze) svým systematickým zkoumáním/pozorováním (Bloch 1998: 22-53, Carrithers 2005: 436-439).

Metafora druhého břehu může být viděna jako sporná, nebot' situuje celou problematiku na dva břehy, a tím rýsuje hranice. V tomto příspěvku jsem však usiloval o zvýznamnění odlišné optiky, která je součástí transnacionální migrace. Jedná se o optiku, která nahlíží, jakým způsobem aktéŕi z druhého břehu vyjednávají svůj život tady a ted' ve vztahu k transnacionálním sítím. Jejich žitá přítomnost je konfrontována s pamětí a vzpomínáním na dobu, kdy sami nevnímali své blízké (Mitmenschen) jako cizince (Nebenmenschen), tedy jako někoho, kdo patři tam, na jiný břeh.

\section{Literatura}

AL-ALI, Nadje. Gender relations, transnational ties and rituals among Bosnian refugees. Global Networks, 2002, č. 2, s. 249-262. ISSN 1470-2266.

AMIT, Vered. Constructing the Field. Ethnographic Fieldwork in the Contemporary World. London: Routledge, 2000. 199 s. ISBN 0-41519-830-5.

APPADURAI, Arjun. Modernity at Large. Cultural Dimensions of Globalization. Minneapolis: University of Minnesota Press, 1996. 224 s. ISBN 0-81662-793-2.

ARGYROU, Vassos. Tradition and Modernity in the Mediterranean: The Wedding as Symbolic Struggle. Cambridge: Cambridge University Press, 1996. 224 s. ISBN 0-52161-984-X.

ASAD, Talal. The Idea of an Anthropology of Islam. Washington D.C.: Georgetown University, 1986. 22 s. ISBN 9-99128-952-6. 
BANKS, Marcus. Visual Methods in Social Research. London: Sage, 2001. 224 s. ISBN 0-76196-364-2.

BAUMANN, Gerd. Ritual Implicates 'Other': Rereading Durkheim in a Plural Society. In COPPET, D. Understanding Rituals. London: Routledge, 1992, s. 97-116. ISBN 0-41506-121-0.

BLOCH, Maurice. How We Think They Think. Oxford: Westview Press, 1998. 216 s. ISBN 0-81333-374-1.

BOISSEVAIN, Jeremy. Patronage in Sicily. Man, 1966, č.1. s. 18-33.

BOS, M. Landmarks for "Nowhereland": scratching the surface of transnational Dutch-Iranian hyperlink networks. Journal of the Royal Anthropological Institute, 2006, č. 12, s. 643-661. ISSN 1359-0987.

BOURDIEU, Pierre. The Logic of Practice. 1. vyd. Stanford: Stanford University Press, 1990. 340 s. ISBN 0-80472-011-8.

BRYCESON, Deborah Fahy; VUORELA, Ulla. Transnational Families in the Twenty-First Century. In BRYCESON, D. F., VUORELA, U. The Transnational Family. New European Frontiers and Global Networks. Oxford: Berg, 2002. s. 3-30. ISBN 1-85973-681-5.

CALLAN, Alyson. What else do we Bengalis do? Sorcery, overseas migration, and the inequalities in Sylhet, Bangladesh. Journal of the Royal Anthropological Institute, 2007, č. 13, s. 331-343. ISSN 1359-0987.

CAMBELL, John K. Honour, family and patronage. Oxford: Clarendon, 1964. 406 s. ISBN 0-19823-122-9.

CARRITHERS, Michael B. Hedgehogs, Foxes and Persons: Resistance and Moral Creativity in East Germany and South India. In ROUGHLEY, N. Being Humans. Anthropological Universality and Particularity in Transdisciplinary Perspectives. New York: Walter de Gruyter, 2000, s. 356-379. ISBN 3-11016-974-6.

CARRITHERS, Michael B. On Polytropy: Or the Natural Condition of Spiritual Cosmopolitanism in India: The Digambar Jain Case. Modern Asian Studies, 2000, č. 34, s. 831-861. ISSN 0026-749X.

CARRITHERS, Michael B. Anthropology as a Moral Science of Possibilities. Current Anthropology, 2005, č. 46, s. 433-456. ISSN 0011-3204.

CARRITHERS, Michael B. From Inchoate Pronouns to Proper Nouns: a Theory Fragment with 9/11, Gertrude Stein, and an East German Ethnography. History and Anthropology, 2008, č. 19, s. 161-186. ISSN 0275-7206.

ELLEN, Roy. Rates of Change: Weasel Words and the Indispensable in Anthropological Analysis. In HANN, C. M. When History Accelerates. London: The Athlone Press, 1994, s. 54-74. ISBN 0-48511-464-X.

ERIKSEN, Thomas Hylland. Nations in cyberspace. Short version of the 2006 Ernest Gellner lecture, delivered at the ASEN conference, London School of Economics, 2006.

FERNANDEZ, James W. Persuasions and Performances: The Play of Tropes in Culture. Bloomington: Indiana University Press, 1986. 324 s. ISBN 0-25320-374-0.

FUGLERUD, Oivind. Life on the Outside: The Tamil Diaspora and Long-distance Nationalism. London: Pluto Press, 1999. 224 s. ISBN 0-74531-433-3. 
GARDNER, Katy. Desh-bidesh: Sylhetti images of home and away. Man, 1993, č. 28. s. 1-15.

GARDNER, Katy. Global Migrants, Local Lives: Travel and Transformation in rural Bangladesh. Oxford: Clarenden, 1995. 320 s. ISBN 0-19827-919-1.

GARDNER, Katy. Global Migrants and Local Shrines: The Shifting Geography of Islam in Sylhet, Bangladesh. In MANGER, L. Muslim Diversity. Local Islam in Global Context. Surrey: Curzon Press, 1999, s. 37-57. ISBN 0-70071-104-X.

GARDNER, Katy. Keeping Connected: Security, Place and Social Capital in A 'Londoni' Village in Sylhet. Journal of the Royal Anthropological Institute, 2008, č. 14, s. 477-495. ISSN 1359-0987.

GARDNER, Katy; GRILLO, Ralph. Transnational households and ritual: an overview. Global Networks, 2002, č. 2, s. 179-190. ISSN 1470-2266.

GARDNER, Katy; AHMED, Zahir. Place, Social Protection and Migration in Bangladesh: A Londoni Village in Biswanath. Working Paper T 18, Development Research Centre on Migration, Globalisation and Poverty. Brighton: University of Sussex, 2006.

GRILLO, Ralph. Transnational Migration and Multiculturalism in Europe. Revised version of a paper originally presented to a ,Symposium on Cultural Diversity and the Construction of Europe: Complementarity or Incompatibility?'. December 2000. University of Oberta, 2001.

GUPTA, Akhil; FERGUSON, James. Anthropological locations: boundaries and grounds of a field science. Berkeley: University of California Press, 1997. 287 s. ISBN 0-52020-680-0.

HANNERZ, Ulf. Transnational Research. In BERNARD, H. R. Handbook of Methods in Cultural Anthropology. Walnut Creek: Altamira Press, 1998, s. 235-256. ISBN 0-74250-432-8.

HASTRUP, Kirsten. A Passage to anthropology. Between experience and theory. London: Routledge, 1995. 232 s. ISBN 0-41512-923-0.

HOLY, Ladislav. Gender and Ritual in an Islamic Society: The Berti of Darfur. Man, 1998, č. 23, s. 469-487.

CHARLSLEY, Katharine. Unhappy Husbands: Masculinity and Migration in Transnational Pakistani Marriages. Journal of the Royal Anthropological Institute, 2005, č. 11, s. 85-105. ISSN 1359-0987.

CHARLSLEY, Katharine. Risk and Ritual: The Protection of British Pakistani Women in Transnational Marriage. Journal of Ethnic and Migration Studies, 2006, č. 32, s. 1169 1187. ISSN 1369-183X.

CHARLSLEY, Katharine; SHAW, A. South Asian transnational marriages in comparative perspective. Global Networks, 2006, č. 6, s. 331-344. ISSN 1470-2266.

KEARNEY, Michael. Reconceptualizing the peasantry: anthropology in global perspective. Critical essays in anthropology. Boulder, Colo: Westview Press, 1996.

LAIDLAW, James. A Free Gift Makes No Friends. The Journal of Royal Anthropological Institute, 2000, č. 6, s. 617-634. ISSN 1359-0987.

LEVITT, Peggy. The Transnational Villagers. Berkeley: University of California Press, 2001. 281 s. ISBN 0-52022-813-8. 
LYON, Stephen M. An Anthropological analysis of local politics and patronage in a Pakistani village. Lampeter: Edwin Mellen Press, 2004. 254 s. ISBN 0-77346-496-4.

MAUSS, Marcel. Esej o daru, podobě a důvodech směny v archaických společnostech. Praha: Slon, 1999. 204 s. ISBN 80-85850-77-X.

NIELSEN, Katrine B. Next Stop Britain: The Influence of Transnational Networks on the Secondary Movement of Danish Somalis. Sussex: Sussex Migration Working Paper no. 22, 2004.

RASANAYAGAM, Johan. Spheres of communal participation: placing the state within local modes of interaction in rural Uzbekistan. Central Asian Survey, 2002, č. 21, s. 55-70. ISSN 0263-4937.

RUSHDIE, Salman. Východ, Západ. Praha: Labyrint, 1997. 165 s. ISBN 80-85935-03-1.

SALIH, Ruba. Reformulating tradition and modernity: Moroccan migrant women and the transnational division of ritual space. Global Networks, 2002, č. 2, s. 219-231. ISSN 1470-2266.

SCHIEFFELIN, Edward L. Performance and the Cultural Construction of Reality. American Ethnologist, 1985, č. 12, s. 707-724. ISSN 0094-0496.

SCHÜTZ, Alfred. The Phenomenology of the Social World. Evanston: Northwestern University Press, 1967. 255 s. ISBN 0-81010-390-7.

STRATHERN, Marilyn. Localism displaced: a "vanishing village" in rural England. Ethnos, 1984, č. 49, s. 43-61. ISSN 0014-1844.

SZALÓ, Csaba. Domov a jiná místa/ne-místa formování kulturních identit. Sociální studia, 2006, č 1, s. 145-160. ISSN 1214-813X.

SZALÓ, Csaba. Transnacionální migrace. Proměny identit, hranic a vědění o nich. Brno: CDK, 2007. 175 s. ISBN 80-7325-136-9.

TAYLOR, Steve; SINGH, Manjit; BOOTH, Deborah. Migration, development and inequality: Eastern Punjabi transnationalism. Global Networks, 2007, č. 7, s. 328-347. ISSN 1470-2266.

VETROVEC, Steven. Cheap calls: the social glue of migrant transnationalism. Global Networks, 2004, č. 4, s. 219-224. ISSN 1470-2266.

WERBNER, Pnina. Economic Rationality and Hierarchical Gift Economies: Value and Ranking Among British Pakistanis. Man, 1990, č. 25, s. 266-285.

WERBNER, Pnina. The Migration Process: Capital, Gifts and Offerings among British Pakistanis. Oxford: Berg, 1990. 400 s. ISBN 1-85973-664-5.

WERBNER, Pnina. Imagined Diaspora among Manchester Muslims: the Cultural Performance of Transnational Identity Politics. 1. vyd. Oxford: James Currey, 2002, 306 s. ISBN 0-85255-920-8.

WERBNER, Pnina. Theorising Complex Diasporas: Purity and Hybridity in the South Asian Public Sphere in Britain. Journal of Ethnic and Migration Studies, 2004. č. 30, s. 895-911. ISSN 1369-183X.

WERBNER, Pnina. The Translocation of culture: "community cohesion" and the force of multiculturalism in history. The Sociological Review, 2005, s. 745-768. ISSN 0038-0261. 


\section{Autor}

Sociální antropolog David Henig je doktorandem na University of Durham (UK). Mezi oblasti jeho výzkumného zájmu patř́ antropologické přístupy $\mathrm{k}$ islámu, postsocialismu a sociální změně. Dále se věnuje antropologické metodologii a možnostem využití informačních technologií při sociokulturní analýze.

Kontakt: david.henig@durham.ac.uk 